3 
Experientia Supplementum

Vol. 44

Springer Basel AG 


\section{Nutritional Adequacy, Nutrient Availability and Needs}

Nestlé Nutrition Research Symposium, Vevey, September 14-15, 1982

Edited by

J. Mauron 
The symposium was organized and sponsored by the

Research Department of Nestlé Products Technical Assistance Co. Ltd., CH-1814 La Tour-de-Peilz (Switzerland)

Volume Editor

Prof. J. Mauron

Research Department

Nestlé Products Technical Assistance Co. Ltd.

P. O. Box 88

CH-1814 La Tour-de-Peilz (Switzerland)

Editorial Board

K. Anantharaman

P. A. Finot

M. Horisberger

Y. Ingenbleek

H. P. Würzner

\section{CIP-Kurztitelaufnahme der Deutschen Bibliothek}

Nutritional adequacy, nutrient availability and needs : Nestlé Nutrition research symposium, Vevey, September 14-15, 1982 / ed. by J. Mauron. [The syposium was organized and sponsored by the Research Dep. of Nestlé Products Techn. Assistance Co. Ltd., La Tour-de-Peilz (Switzerland). Ed. board K. Anantharaman ....].

Basel ; Boston ; Stuttgart : Birkhăuser. - 1983.

(Experientia : Suppl. ; Vol. 44)

NE: Mauron, Jean [Hrsg.]; Nestlé Nutrition SA 〈Vevey) ;

Experienta / Supplementum

All rights reserved.

No part of this publication may be reproduced, stored in a retrieval system, or transmitted in any form or by any means, electronic, mechanical, photocopying, recording or otherwise, without the prior permission of the copyright owner.

(C) 1983 Springer Basel AG

Originally published by Birkhăuser Verlag Basel in 1983.

Softcover reprint of the hardcover 1st edition 1983

ISBN 978-3-0348-6542-5 ISBN 978-3-0348-6540-1 (eBook)

DOI 10.1007/978-3-0348-6540-1 
C ONTENTS

Introduction

J. Mauron

How much food does man require ? An evaluation of human energy needs

E.M. Widdowson

Thermogenic responses induced by nutrients in man :

Their importance in energy balance regulation

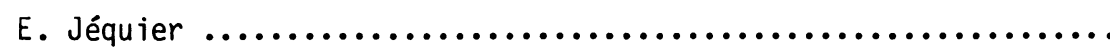

Energy expenditure and whole body protein synthes is in very low birth weight (VLBW) infants

Y. Schutz, C. Catzeflis, F. Gudinchet, J. Micheli,

C. Welsch, M.J. Arnaud and E. Jéquier

Energy fuel and hormonal profile in experimental obesities

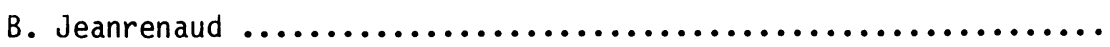

Nutrient intake and energy regulation in physical exercise

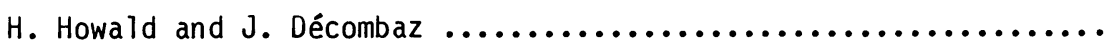

Protein turnover, nitrogen balance and rehabilitation

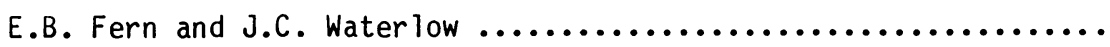

Amino acid signals and food intake and preference : Relation

to body protein metabolism

A.E. Harper and J.C. Peters

Food processing and storage as a determinant of protein and amino acid availability

R.F. Hurrell and P.A. Finot 
Energy/protein interrelation in experimental food restriction

K. Anantharaman

Behavioural strategies in the regulation of food choice

P.D. Leathwood and D.V.M. Ashley

The relationship of pellagra to corn and the low availability of niacin in cereals

K.J. Carpenter

Iron requirements and bioavailability of dietary iron

L. Hallberg

Vitamin deficiencies in rice-eating populations.

Effects of B-vitamin supplements

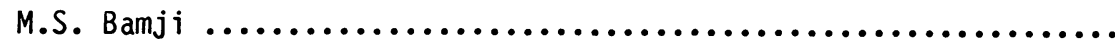

Vitamin A-deficiency impairs the normal mannosylation, conformation and iodination of thyroglobulin : A new etiological approach to endemic goitre

Y. Ingenbleek

Is the adult protein-energy malnutrition syndrome the same

as that described in the infant?

J. Mauron and I. Antener

Public health/clinical significance of inorganic chemical elements

M. Abdulla

Food consumption, neurotransmitter synthesis, and human behaviour

R.J. Wurtman

General remarks - Some personal reflections

A.E. Bender 